\title{
Identifikasi Daging Sapi Segar Dan Beku Menggunakan Learning Vector Quantization
}

\section{Identification of Fresh and Frozen Beef Using Learning Vector Quantization}

\author{
Lilis Cahyono ${ }^{1}$, Supatman ${ }^{2}$ \\ ${ }^{1,2}$ Program Studi Teknik Informatika, Fakultas Teknologi Informasi, Universitas Mercu Buana Yogyakarta, \\ Jl. Wates Km. 10 Yogyakarta 55753, Indonesia \\ E-mail: liliscahyono15@gmail.com ${ }^{1}$, supatman@mercubuana-yogya.ac.id ${ }^{2}$
}

\begin{abstract}
ABSTRAK
Di Indonesia harga daging sapi cukup mahal, hal ini terjadi karena mata rantai distribusi yang sangat panjang dari peternak hingga ke tangan konsumen, sehingga diperlukan biaya yang sangat tinggi untuk membeli daging sapi. Dengan mahalnya daging sapi tersebut ada beberapa oknum yang berusaha mencampur kualitas kesegaran daging sapi dengan mencampurnya antara daging yang baru dipotong dengan daging yang sudah dipotong beberapa waktu. Kondisi ini sangat merugikan konsumen yang membeli daging sapi. Saat ini identifikasi daging dilakukan secara kasat mata maupun dengan menekan dagingnya untuk mengetahui tekstur daging. Cara ini memiliki banyak kelemahan bila para konsumen tidak jeli untuk membedakan kualitas kesegaran daging sapi. Perkembangan ilmu pengetahuan dan teknologi pengolahan citra digital memungkinkan untuk memilih kualitas kesegaran daging sapi tersebut secara otomatis dengan bantuan aplikasi pengolahan citra. Tujuan dari penelitian ini adalah mengembangkan algoritma untuk mengidentifikasi daging sapi segar dan sapi beku menggunakan Learning Vector Quantization $(L V Q)$. Jumlah data pelatihan yang digunakan terdiri dari 2 kelas (kelas 1 : kelas daging segar dan kelas 2 : daging sapi beku), masing-masing kelas berjumlah 15 data pelatihan, jadi total data berjumlah 30 data pelatihan. Sedangkan untuk data uji masing-masing kelas menggunakan 20 data uji dengan total berjumlah 40 data uji. Pada proses pelatihan menggunakan Learning Vector Quantization diperoleh unjuk kerja identifikasi terbaik sebesar $96,67 \%$ pada parameter dec alfa (dec $\alpha$ ) 0,75 dengan alfa $(\alpha) 0,00001$. Bobot akhir yang diperoleh dari hasil learning tersebut kemudian digunakan untuk melakukan pengenalan data uji. Unjuk kerja terbaik pengujian dengan presentase komulatif mencapai $80 \%$ yaitu data mengenali daging segar 12 pada kelas 1 dan data mengenali daging sapi beku 20 pada kelas 2 .
\end{abstract}

Kata Kunci: Daging Sapi, Learning Vector Quantization (LVQ).

\begin{abstract}
In Indonesia the price of beef is quite expensive, this happens because the chain of distribution is very long from farmers to consumers, so it requires a very high cost to buy beef. With the high price of beef, there are some people who try to mix the quality of freshness of beef by mixing it between freshly cut meat and meat that has been cut for some time. This condition is very detrimental to consumers who buy beef. Currently identification of meat is done by naked eye and by pressing the meat to find out the texture of the meat. This method has many disadvantages if consumers are not observant to distinguish the quality of freshness of beef. The development of science and digital image processing technology makes it possible to choose the quality of freshness of beef automatically with the help of image processing applications. The purpose of this study is to develop an algorithm to identify fresh beef and frozen beef using Learning Vector Quantization ( LVQ). The amount of training data used consisted of 2 classes (class 1: fresh meat class and class 2: frozen beef), each class consisted of 15 training data, so the total data amounted to 30 training data. While for the test data each class uses 20 test data with a total of 40 test data. In the training process using Learning Vector Quantization the best identification performance was $96.67 \%$ in the dec alpha (dec $\alpha$ ) 0.75 parameter with alpha ( $\alpha$ ) 0.00001 . The final weight obtained from the learning results is then used to introduce test data. The best performance
\end{abstract}


testing with a cumulative percentage of $80 \%$ is data recognizing fresh meat 12 in class 1 and data recognizing frozen beef 20 in class 2.

Keywords: Beef, Learning Vector Quantization (LVQ), Neural Network (NN)

\section{PENDAHULUAN}

Daging merupakan salah salah satu produk pangan berasal dari hewani yang mempunyai gizi tinggi karena mengandung karbohidrat, protein, lemak, vitamin, dan mineral. Daging adalah bagian yang diperoleh dari pemotongan ternak, baik ternak besar seperti sapi, kerbau, kuda, maupun ternak kecil seperti kambing, domba maupun ternak unggas, dan lain-lain (Faizun, I. J. 2017).

Daging sapi merupakan jenis daging yang banyak dikonsumsi masyarakat di seluruh belahan dunia termasuk indonesia. Menurut Kementrian Kesehatan Republik Indonesia, dalam 100 gram sapi memilik kandungan energi sebesar 207 kilokalori, protein 18,8 gram, lemak 14gram, kalsium 11 miligram, fosfor 170 miligram, dan zat besi 3 miligram. Selain itu di dalam daging sapi mengandung vitamin A 30 UI, vitamin B I 0,08 miligram dan vitamin C 0 miligram. Banyak kandungan gizi pada daging sapi tentunya sangat bermanfaat bagi tubuh manusia apabila mengkonsumsi daging sapi. Berbanding terbalik apabila dengan daging yang sudah busuk, maka akan menimbulkan penyakit bagi yang mengkonsumsinya (Faizun, I. J. 2017).

Berdasarkan uraian tersebut penulis mengambil penelitian dengan judul "Identifikasi Daging Sapi Segar Dan Beku Menggunakan Neural Network" dengan harapan bisa mengembangkan aplikasi untuk mengidentifikasi tekstur daging sapi.

\section{TINJAUAN PUSTAKA}

Sutarno, (2010), melakukan penelitian untuk mengetahui tingkat keberhasilan sistem identifikasi citra menggunakan transformasi wavelet, mengetahui pengaruh transformasi dengan berbagai metode wavelet citra masukan terhadap unjuk kerja sistem identifikasi citra. Citra untuk pengujian diambil dilapangan menggunakan kamera digital. Pada pengujian awal proses transformasi citra masukan menggunakan wavelet Haar hingga level-3. Pada proses pengujian selanjutnya transformasi citra masukan akan menggunakan keluarga wavelet Daubechles (db2) dan Coiflets (coif).
Abdul fadlil, (2012), melakukan penelitian untuk mengidentifikasi tekstil berbasis komputer dengan memasukan informasi dari citra kain ke dalam komputer. Selanjutnya komputer menerjemahkan serta mengindentifikasi jenis kain tersebut. Pada pengembangan sistem ini terdiri dari 2 yaitu tahap penentuan pola standar referensi dan pengujian. Data yang digunakan sebagai standar referensi sebanyak 5 sampel untuk masingmasing jenis kain yaitu blacu,finished dan rajut. Sedangkan untuk pengujian untuk kerja sistem mengunakan 100 sampel untuk masing-masing jenis kain. Pengujian untuk kerja sistem dilakukan dengan melakukan variasi ukuran citra dan metode matrik jarak. Hasil pengujian sistem identifikasi citra kain menunjukan tingkat akurasi yang tinggi sebesar $93 \%$ untuk ukuran citra asli 600x800 dengan metode ektraksi ciri histogram dan teknik klasifikasi matrik jarak Squared Chi Squared.

Setelah dipotong, daging harus segera ditangani dengan cara yang tepat supaya daging tidak cepat rusak dan kandungan gizi di dalamnya tidak menurun. Kandungan gizi yang cukup tinggi tersebut merupakan media yang ideal bagi pertumbuhan mikroorganisme dan adanya aktivitas enzim, sehingga daging cepat mengalami kerusakan (Jaelani, 2014).

\section{METODOLOGI PENELITIAN}

Secara garis besar penelitian ini dibagi menjadi 4 tahapan, yaitu : (1) Akusisi data, (2) Proses ekstraksi fitur, (3) Pelatihan dengan LVQ, (4) Pengujian dengan LVQ. Desain jalannya penelitian dapat dilihat pada Gambar 1.

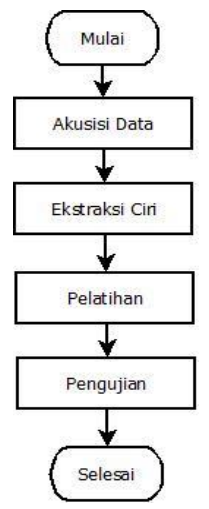

Gambar 1 Desain Sistem 


\subsection{Akusisi Data}

Akusisi data merupakan tahapan awal yang dilakukan dalam pengidentifikasian citra daging sapi. Alat yang digunakan berupa kamera handphone Lenovo. Pengambilan citra dilakukan langsung oleh peneliti terhadap daging sapi yang biasanya digunakan untuk lauk dan makanan sehari-hari.

\subsubsection{Data}

Dari proses akuisisi data yang dilakukan maka akan dihasilkan data berupa citra daging sapi. Citra ini selanjutnya akan dilakukan pemrosesan pada tahap berikutnya.

\subsection{Preprossesing}

\subsubsection{Cropping}

Cropping citra daging sapi dilakukan untuk memotong ukuran citra yang akan diproses. Citra yang akan diproses memiliki dimensi 1746x3104 menjadi 500x500 piksel. Hal ini dilakukan untuk mempercepat proses komputasi.

\subsubsection{Grayscaling}

Setelah citra di-rezize, proses selanjutnya adalah mengubah citra tiga layer menjadi satu layer gray. Proses dari grayscale ditunjukan pada Gambar 2.

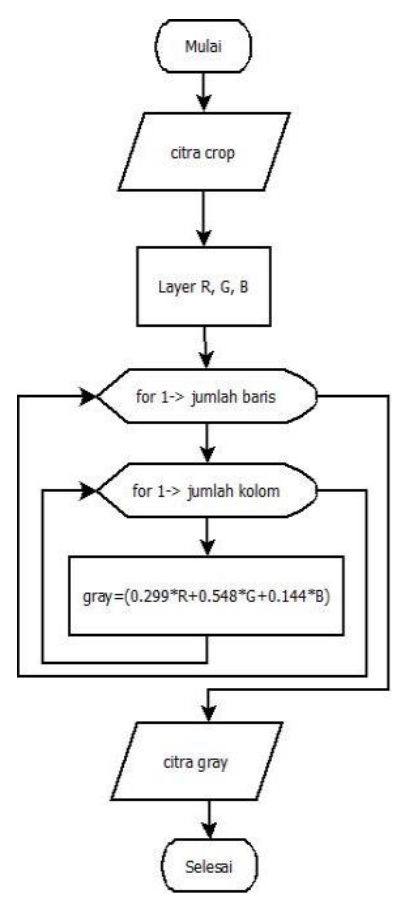

Gambar 2 Diagram Alir Proses Grayscale

Keterangan:

Citra crop : Citra yang didapat dari proses crop

Layer R : Layer merah dari citra crop

Layer $\mathrm{G} \quad$ : Layer hijau dari citra crop
Layer B : Layer biru dari citra crop

baris : banyaknya piksel baris dari citra crop

kolom : banyaknya piksel kolom dari citra crop

citra gray : citra yang dihasilkan dari proses grayscale

\subsection{Wavelet}

Wavelet yang digunakan yaitu wavelet level 1 , level 2 , level 3. Data citra yang sudah menjadi grayscale ditransformasikan yang kemudian dibagi menjadi 4 sub-image baru yaitu CA (Coefficients Approximation), $\quad \mathrm{CH}$ (Coefficients Horizontal), CV (Coefficients Vertical) dan CD (Coefficients Diagonal) level 1. Kemudian diproses wavelet level 2, citra CA dari level 1 dibagi lagi menjadi $\mathrm{CA}, \mathrm{CH}, \mathrm{CV}$, dan $\mathrm{CD}$. Pada wavelet level 3caranya seperti pada level 2 dengan mengambil $\mathrm{CA}$ level 2 kemudian dibagi menjadi $\mathrm{CA}, \mathrm{CH}, \mathrm{CV}$, dan $\mathrm{CD}$. Diagram alir dari transformasi wavelet ditunjukkan pada Gambar 3.

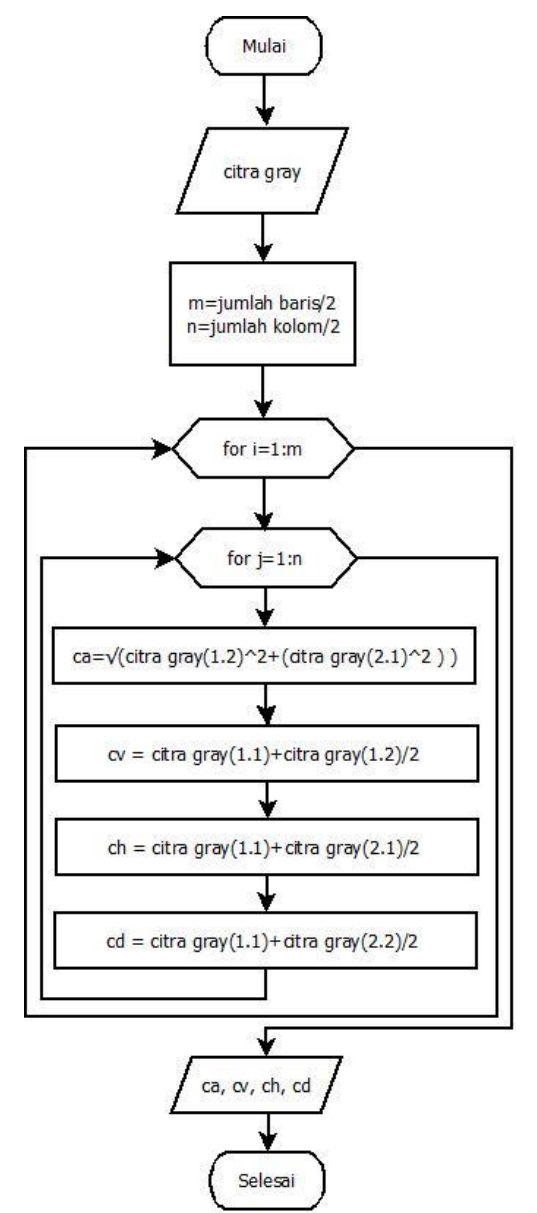

Gambar 3 Diagram Alir Proses Wavelet

Keterangan: 


$\begin{array}{ll}\text { baris } & \text { : banyaknya piksel bari dari citra } \\ & \text { gray } \\ \text { kolom } & \text { : banyaknya kolom bari dari citra } \\ & \text { gray } \\ \text { ca } & \text { : citra aproksimasi } \\ \text { ch } & \text { : citra horizontal } \\ \mathrm{cv} & \text { : citra vertical } \\ \mathrm{cd} & \text { : citra diagonal }\end{array}$

\subsection{Ektraksi Ciri}

Ektraksi ciri merupakan langkah awal dalam melakukan klasifikasi dan interpretasi citra. Proses ini berkaitan dengan kuantisasi karakteristik citra ke dalam sekelompok nilai ciri yang sesuai. Sehingga mendapatkan informasi kuantiatif dari citra yang membedakan kelaskelas suatu obyek. Dalam penelitian ini menggunakan komponen mean ciri yang diambil dari komponen ciri mean (rerata), standar deviasi (std) dan (var) yang diambil dari wavelet level 1 sampai level 3.

\subsection{Fitur Vector}

Setelah melakukan ektraksi ciri dari citra daging sapi maka akan diperoleh sebuah ciri dalam bentuk vector. Ciri tersebut kemudian disimpan dalam database yang digunakan sebagai acuan untuk mendapatkan bobot awal. Dari proses pelatihan akan diperoleh bobot akhir. Pengenalan data uji dilakukan dengan dengan membandingkan bobot akhir dengan ciri data uji, kemudian mencari jarak terdekat untuk menentukan kelasnya.

\subsection{Learning Vector Quantization}

Learning Vector Quatization (LVQ) adalah sebuah metode klasifikasi dimana setiap unit output mempresentasikan sebuah kelas. $L V Q$ digunakan untuk pengelompokan,dimana jumlah kelompok sudah ditentukan arsitekturrnya (target/kelas sudah ditentukan). Sehingga dapat melakukan proses identifikasi untuk mengetahui jenis daging sapi segar dan daging sapi beku. Berikut adalah topologi jaringan LVQ yang ditunjukkan pada Gambar 4.

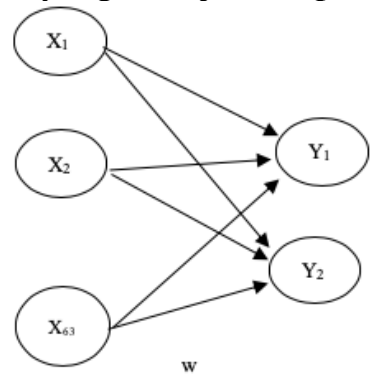

Gambar 4 Topologi Jaringan LVQ
Keterangan:

$\mathrm{X} 1, \ldots \mathrm{X} 63=$ Vektor input.

$\mathrm{Y}_{1}, \mathrm{Y}_{2}=$ Kelas (kelas 1 dan kelas 2 )

$\mathrm{W}=$ Bobot

Berdasarkan topologi jaringan tersebut dapat dimasukan kedalam proses LVQ untuk melakukan pengenalan citra daging sapi. Diagram alir LVQ ditunjukan pada Gambar 5.

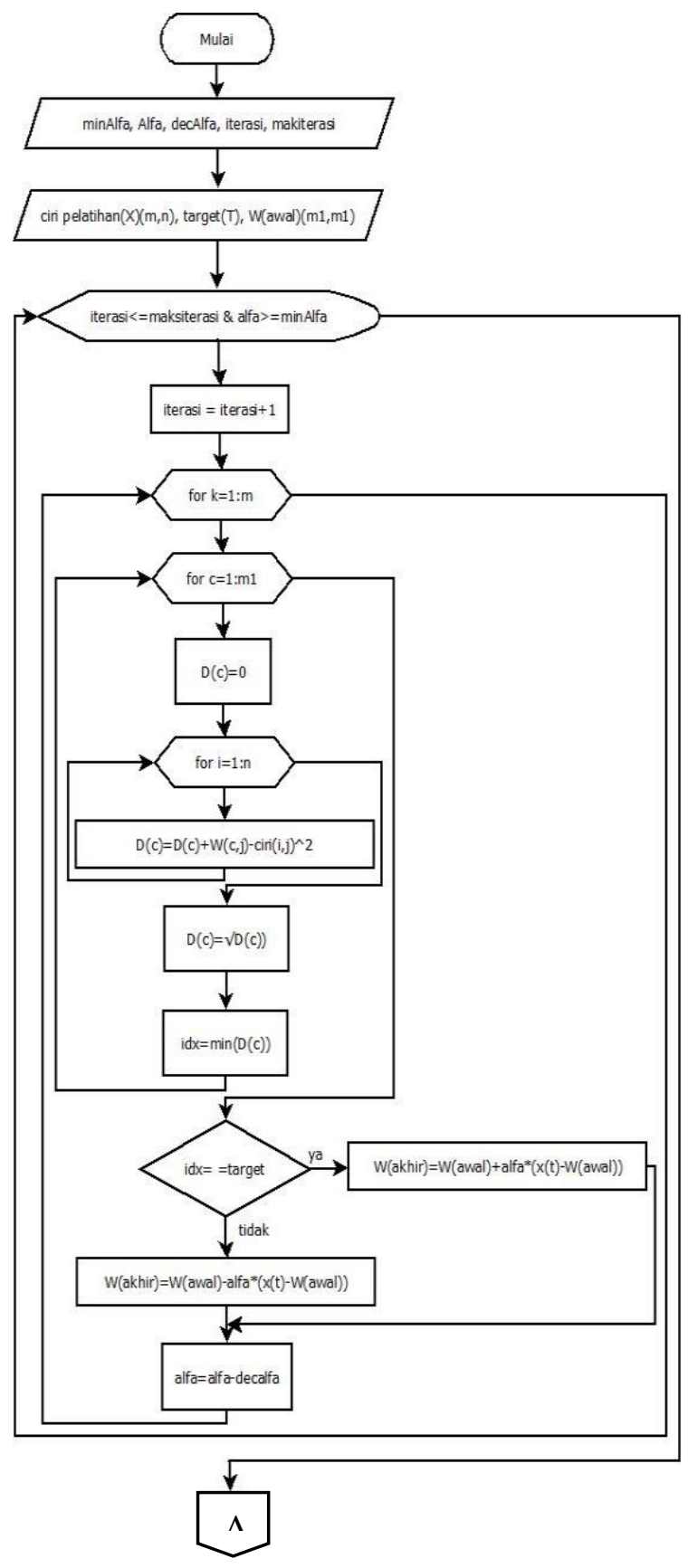




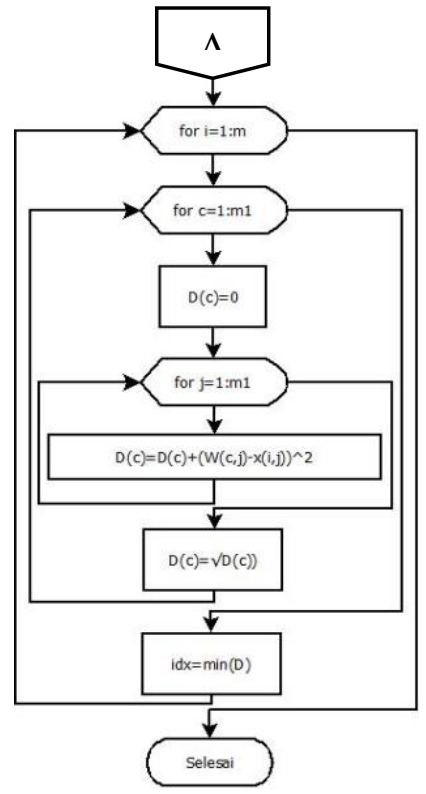

Gambar 5 Diagram Alir Learning Vector Quantization

Keterangan:

W(awal) : bobot awal

W(akhir) : bobot akhir

$\mathrm{D}$ (c) : jarak kelas 1 dan kelas 2

m,n : baris dan kolom matriks data pelatihan

m1,n1 : baris dan kolom matriks bobot awal

idx $\quad$ : jarak terdekat

\section{PEMBAHASAN}

\subsection{Hasil Penelitian}

Hasil dari penelitian yang telah dilakukan dalam proses klasifikasi jenis daging sapi untuk mengetahui tekstur daging sapi segar dan daging sapi beku. Penelitian ini dilakukan beberapa kali agar mendapatkan hasil yang akurat dan maksimal. Penelitian yang pertama menggunakan sampel tekstur daging sapi menggunakan 40 citra daging sapi, dengan rincian 20 citra dijadikan sebagai data pelatihan dan 20 citra dijadikan sebagai data uji. Selanjutnya penelitian yang kedua menggunakan sampel tekstur daging sapi menggunakan 60 citra daging sapi, dengan rincian 30 citra dijadikan sebagai data pelatihan dan 30 citra dijadikan sebagai data uji, akan tetapi belum menghasilkan nilai yang terbaik. Peneliti melakukan data uji yang terakhir dengan hasil yang terbaik dengan sampel tekstur daging sapi menggunakan 70 citra daging sapi, dengan rincian 30 citra dijadikan sebagai data pelatihan dan 40 citra dijadikan sebagai data uji.

Sementara untuk kelas dalam penelitian ini terdapat dua kelas, yaitu daging sapi segar dan daging sapi beku. Metode yang digunakan dalam penelitian ini untuk mengidentifikasi daging sapi segar dan saging sapi beku menggunakan jaringan syaraf tiruan Learning Vector Quantification (LVQ).

\subsubsection{Akuisisi Citra}

Data citra diambil menggunakan kamera telefon genggam. Citra yang diambil adalah citra daging sapi segar dan citra daging sapi beku. Pencarian data yaitu dengan mendatangi supermarket-supermarket terdekat untuk mendapatkan daging sapi segar yang sudah terpotong kecil-kecil agar nantinya lebih mudah saat pengambilan citra data. Untuk pengambilan citra daging sapi segar dilakukan saat kondisi daging sapi masih segar, sedangkan untuk pengambilan citra daging sapi beku perlu menunggu beberapa waktu sampai daging membeku selanjutnya baru dilakukan proses pengambilan citra daging sapi beku.

Hasil akuisisi berupa citra digital dengan format jpg dipindahkan ke komputer untuk dijadikan data dalam penelitian. Data citra daging sapi segar ditunjukkan oleh Gambar 6 .

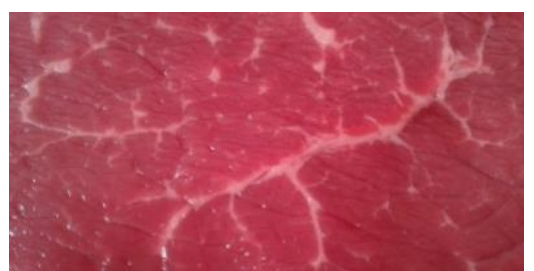

Gambar 6 Citra Daging Sapi Segar

Sedangkan untuk hasil data citra daging sapi beku ditunjukkan oleh Gambar 7 .

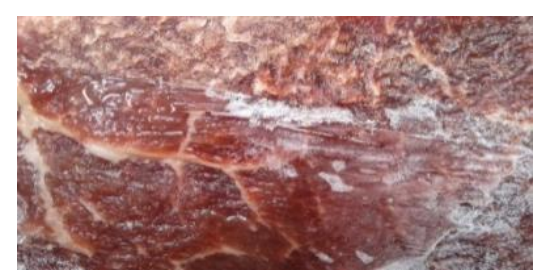

Gambar 7 Citra Daging Sapi Beku

\subsubsection{Preprossesing}

\subsubsection{Cropping}

Tahap selanjutnya adalah preprocessing dan tahap ini dilakukan beberapa tahapan, yaitu cropping, grayscale. Cropping dilakukan agar area data ciri citra yang diproses menjadi lebih spesifik. Data citra di-cropping dengan dimensi 500x500 piksel. Data citra cropping daging segar ditunjukkan pada Gambar 8. 


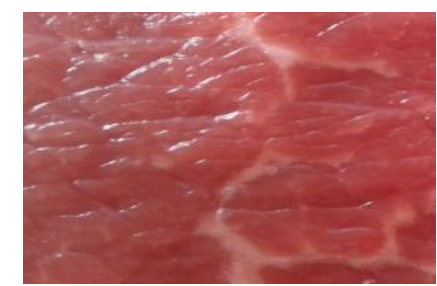

Gambar 8 Hasil Cropping Citra Daging Segar

Sedangkan untuk data citra hasil proses cropping daging beku ditunjukkan pada Gambar 9.

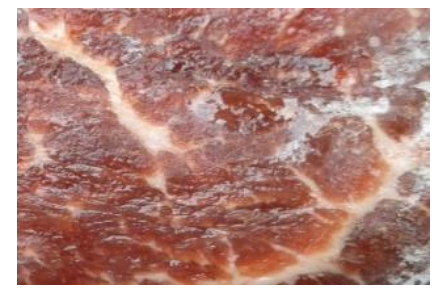

Gambar 9 Hasil Cropping Citra Daging Beku

\subsubsection{Grayscale}

Setelah dimensi citra di-cropping kemudian tahap selanjutnya dilakukan proses grayscale dengan mengubah citra tiga layer $\mathrm{R}$, layer $\mathrm{G}$, layer $\mathrm{B}$ menjadi satu layer gray dengan menggunakan proses grayscaling atau mengubah citra menjadi aras keabuan. Proses grayscaling dilakukan dengan mempersatukan layer RGB menjadi satu menggunakan komponen YUV yang dilakukan dengan setiap layer dan dari hasil perkalian tersebut dijumlahkan. Data citra gray ditunjukkan pada Gambar 10.

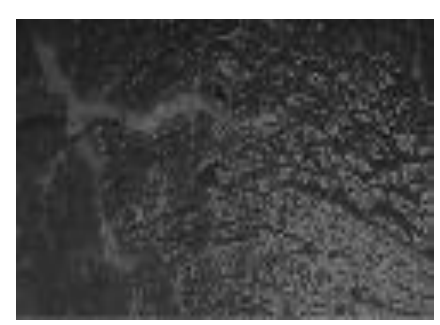

Gambar 10 Citra Gray

\subsubsection{Wavelet}

Pada tahap selanjutnya, citra kemudian diolah dengan algoritma wavelet. Wavelet yang digunakan level 1 sampai level 3. Data citra setelah melalui preprossesing dibagi menjadi 4 yaitu CA, CH, CV, CD untuk level 1. Pengambilan ciri dilakukan pada setiap komponen wavelet dari level 1 sampai level 3.

\subsubsection{Wavelet Level 1}

Hasil wavelet level 1 pengenalan tekstur citra daging sapi yang memiliki satu bagian

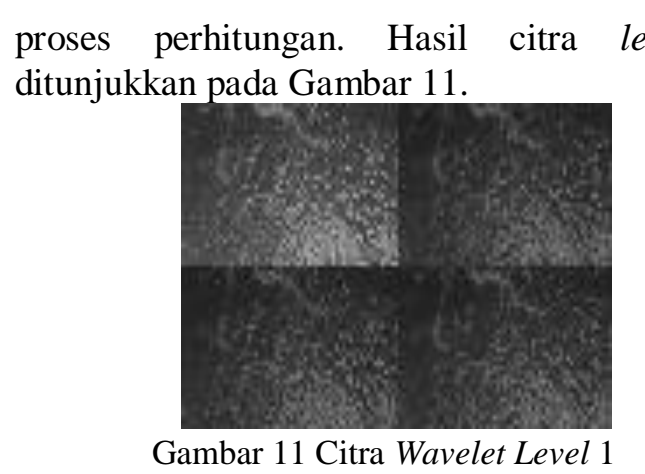

\subsubsection{Wavelet Level 2}

Setelah melalui proses level 1 , hasil citra wavelet level 1 akan dibagi menjadi 4 bagian. Sehingga pada level 2 terdapat 4 bagian dalam perhitungan wavelet. Hasil citra level 2 ditunjukkan pada Gambar 12.

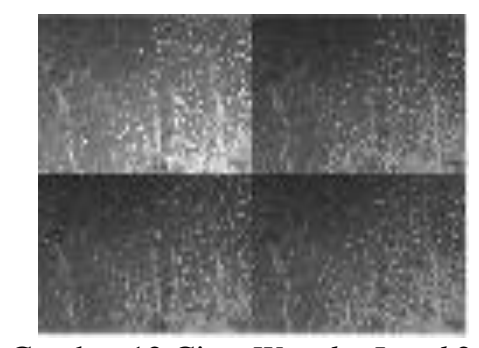

Gambar 12 Citra Wavelet Level 2

\subsubsection{Wavelet Level 3}

Citra wavelet level 3 memiliki 16 bagian yang dihasilkan dari pembagian citra pada level 2 yang setiap bagian citra level 2 dibagi 4 bagian. Citra wavelet level 3 ditunjukkan pada Gambar 13.

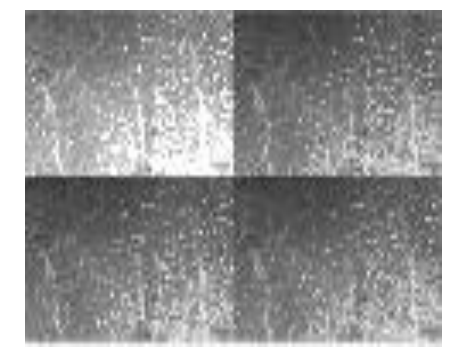

Gambar 13 Citra Wavelet Level 3

\subsubsection{Ekstraksi Ciri}

Setelah proses wavelet kemudian dilakukan ekstraksi menggunakan mean, standart deviasi dan varian pada citra CA, CV, $\mathrm{CH}$ dan $\mathrm{CD}$ dari level 1 sampai level 3. Sehingga terdapat 63 ciri untuk satu vektor. Ekstraksi ciri data pelatihan menggunakan 30 data citra dengan rincian 15 data citra daging sapi segar dan 15 data citra daging sapi beku. Sedangkan Ektraksi ciri untuk data uji menggunakan 40 data 
citra dengan rincian 20 citra daging sapi segar dan 20 citra daging sapi beku.

\subsubsection{Fitur Vector}

Setelah melakukan ekstraksi ciri dari citra daging sapi maka akan diperoleh sebuah ciri dalam bentuk vector. Ciri tersebut kemudian disimpan dalam database yang digunakan sebagai acuan untuk proses pelatihan. Dari proses pelatihan akan diperoleh bobot akhir. Pengenalan data uji dilakukan dengan membandingkan bobot akhir dengan ciri data uji, kemudian mencari jarak terdekat untuk menentukan kelasnya.

\subsubsection{Artificial Neural Network}

Pada proses pelatihan pada jaringan Artificial Neural Network LVQ digunakan parameter untuk mengetahui presentase keberhasilan tertinggi. Parameter ANN LVQ dalam pelatihan ditunjukkan pada Tabel 1 .

Tabel 1 Parameter ANN LVQ

\begin{tabular}{|l|l|}
\hline \multicolumn{1}{|c|}{ Parameter } & \multicolumn{2}{c|}{ Keterangan } \\
\hline Jumlah Data Pelatihan & 30 \\
\hline Jumlah Data Uji & 40 \\
\hline Jumlah Pola Target & 2 \\
\hline
\end{tabular}

\begin{tabular}{|l|l|}
\hline \multicolumn{1}{|c|}{ Parameter } & \multicolumn{1}{c|}{ Keterangan } \\
\hline $\begin{array}{l}\text { Variasi Laju Pelatihan } \\
(\alpha)\end{array}$ & 0,$1 ; 0,01 ; 0,001 ;$ \\
0,$0001 ; 0,00001$
\end{tabular}

\subsubsection{Unjuk Kerja}

Dalam menentukan hasil kinerja identifikasinya bisa dilakukan dengan mengubah parameter laju pelatihan awal (alfa) dan penurunan laju pelatihan (decalfa). Untuk target ada 2, nilai minimum laju pelatihan (min alfa) adalah 0,00001, dan maksimal iterasi (epoch) nilainya 250 .

Hasil unjuk kerja citra pelatihan mendapatkan presentase keberhasilan terbaik, yaitu pada dec alfa (deca) 0,75 dengan alfa ( $\alpha$ ) 0,00001 pada iterasi kedua yang menghasilkan presentase $96,67 \%$ menggunakan data pelatihan dengan rincian 15 citra daging sapi segar dan 15 citra daging sapi beku.

Sedangkan hasil pengenalan data uji per data menggunakan 40 citra data uji. Dari 40 citra data uji tersebut menghasilkan presentase komulatif sebesar $80 \%$ yaitu dengan rincian 20 citra untuk kelas 1 milik daging sapi segar dapat mengenali 12 citra data uji sedangkan 8 tidak termasuk data kelas 1. Data citra uji kelas 2 milik daging sapi beku dapat mengenali 20 data citra data uji.

\subsubsection{Analisis Dan Pembahasan}

Sebelum dilakukan ekstraksi ciri, data ciri yang sudah dilakukan preprosessing seperti yang dijelaskan pada bab sebelumnya. Dari data citra tersebut kemudian diproses melalui tahap wavelet diambil ciri citra dengan menggunakan rerata ( mean), standar deviasi dan varian yang akan dijadikan. Kemudian dipilih satu citra untuk setiap kelasnya untuk dijadikan bobot awal. Dari bobot awal tersebut diolah menggunakan LVQ untuk mendapatkan bobot akhir. Proses pelatihan dilakukan untuk mengenali target yang telah ditentukan. Data pelatihan memiliki 2 kelas yaitu untuk kelas 1 milik daging sapi segar dan kelas 2 milik daging sapi beku.

Setelah bobot akhir didapatkan maka akan diproses pencarian jarak terdekat antara bobot akhir dengan ciri citra data uji. Sehingga akan mendapatkan jarak terdekat yang memungkinkan hasil antara kelas 1 dan kelas 2 .

Dari hasil pelatihan data menunjukkan terdapat presentase keberhasilan terbaik yaitu pada dec alfa (dec $\alpha)$ 0,75 dengan alfa ( $\alpha$ ) 0,00001 pada iterasi kedua yang menghasilkan presentase $96,67 \%$.

Sedangkan hasil pengenalan data uji per data pengujian dengan 40 citra data uji dengan rincian 20 citra untuk kelas 1 milik daging sapi segar dapat mengenali 12 citra data uji sedangkan 8 tidak termasuk data kelas 1. Data citra uji kelas 2 milik daging sapi beku dapat mengenali 20 data citra data uji. Dengan presentase komulatif $80 \%$.

\section{KESIMPULAN}

Kesimpulan yang dapat diambil dari penelitian Identifikasi Daging Sapi Segar Dan Beku Menggunakan Neural Network adalah sebagai berikut :

1. Hasil unjuk kerja terbaik pada pelatihan dengan presentase komulatif mencapai 96,67\% pada parameter dec alfa (dec $\alpha$ ) 0,75 dengan alfa $(\alpha)$ 0,00001 menggunakan data pelatihan 15 citra daging sapi segar dan 15 citra daging sapi beku.

2. Hasil unjuk kerja pada pengujian dengan presentase komulatif mencapai $80 \%$ 
menggunakan data pengujian dengan rincian 20 citra daging sapi segar dan 20 citra daging sapi beku.

\section{DAFTAR PUSTAKA}

Bany, R. (2015). Sistem Identifikasi Menggunakan Biometrik Telinga Dengan Metode Jaringan Syaraf Tiruan LearningVector Quantization (LVQ). Universitas Sriwijaya, Palembang.

Budiarso, Y. (2010). Identifikasi Macan Tutul Dengan Metode Grey Level Coocurent Matrix. Universitas Stikubank, Semarang.

Fadhil, A. (2012). Sistem Pengenalan Citra Jenis-Jenis Tekstil. Universitas Ahmad Dahlan, Yogyakarta.

Faizun, I. J. (2017). Identifikasi Tingkat Kesegaran Daging Sapi Lokal Menggunakan Ekstraksi Fitur Warna Berbasis GUI Matlab. Universitas Lampung, Bandar Lampung.

Fitriyadi, \& Sutikno. (2016). Pengenalan Jenis Golongan Darah Menggunakan Jaringan Syaraf Tiruan Perceptron. Universitas Diponegoro, Semarang.

Jaelani , A. S Dharmawati, \& Wanda. (2014). Berbagai Lama Penyimpanan Daging Ayam Broiler Segar Dalam Kemasan Plastik Pada Lemari Es (Suhu 4 Derajat Celcius) Dan Pengaruhnya Terhadap Fisik Dan Organoleptik. Vol 39 (3) : 119-128.

Kadir, A., \& Susanto, A. (2012). Teori dan Aplikasi Pengolahan Citra. Yogyakarta: Andi.

Kiswanto. (2013). Identifikasi Jenis Daging Sapi Menggunakan Transformasi Wavelet
Haar. Universitas Diponegoro, Semarang.

Kuntoro, Maheswari, \& Nuraini. (2013). Mutu Fisik Dan Mikrobiologi Daging Sapi Asal Rumah Potong Hewan (RPH). Fakultas Pertanian Dan Peternakan UIN Suska Riau.

Kusumadewi, S (2010). Pengantar Jaringan Syaraf Tiruan. Yogyakarta. Teknik Informatika FT UII.

Nicky Astriyanti. (2015). Identifikasi Varietas Durian Berdasarkan Citra Daun Menggunakan LVQ dan Ektrasi Ciri Discrete Wavelet Transform. Institut Pertanian Bogor.

Novia, L., \& Lucky, L. (2017). Impelentasi Jaringa Syaraf Tiruan Untuk Menilai Kelayakan Tugas Akhir Mahasiswa. Universitas Lancang Kuning, Riau.

Putra, D. (2010). Pengolahan Citra Digital. Yogyakarta: Andi.

Siang, J. J. (2009). Jaringan Syaraf Tiruan dan Pemrogramannya Menggunakan Matlab. Yogyakarta: Andi.

Sri Hartati, C. D. (2012). Populasi Mikroba Dan Sifat Fisik Daging Sapi Beku Selama Penyimpanan. Universitas Mercu Buana Yogyakarta, Yogyakarta.

Sutarno. (2010). Analisis Perbandingan Transformasi Wavelet pada Pengenalan Citra Wajah. Sumatra Selatan: Universitas Sriwijaya.

T. Sutoyo, E. Mulyanto, V. Suhartono, O. D Nurhayati \& Wijanarto (2009). Teori Pengolahan Citra Digital. Penerbit Andi : Yogyakarta.

Zurriyati, Y. (2011). Palatabilitas Bakso Dan Sosis Sapi Asal Daging Segar, Daging Beku Dan Produk Komersial. Universitas Pekanbaru. 